\title{
Special issue on Governance and accounting regulation
}

\author{
Roberto Di Pietra ${ }^{1} \cdot$ Günther Gebhardt ${ }^{2}$. Stuart McLeay ${ }^{3}$
}

Accepted: 1 December 2020 / Published online: 23 April 2021

(c) The Author(s), under exclusive licence to Springer Science+Business Media, LLC, part of Springer Nature 2021

The first workshop on Accounting Regulation was organized in Siena in 1998, in the historic Certosa di Pontignano. Since then, this three-yearly international research meeting has taken place another seven times, in various locations within the city of Siena. The most recent Workshop was held in July 2019.

Over the years, an extensive community of scholars has taken the opportunity to meet and discuss the role of regulation within the wider domain of accountability, financial reporting and governance-the working papers presented during the eight workshops have led to eventual publication in accounting research journals throughout the world. To date, two books have collected together reprints of the published versions of some of the papers presented in the past (McLeay \& Riccaboni, 2001; Di Pietra, McLeay \& Ronen, 2014). Moreover, together with this present issue of the Journal of Management and Governance (JMG), a total of five Special Issues have helped us to draw attention to the far-reaching debate surrounding Accounting Regulation.

In summary, a total of 34 papers have been published in the previous 4 Special Issues on Accounting Regulation, providing 67 authors and coauthors-including early career researchers-with the opportunity to disseminate the results that were first presented at the Siena workshops. These JMG Special Issue papers have generated more than 38,000 downloads to date as well as over 200 citations.

The present issue of the JMG is the latest in this series. The 2019 Workshop provided a forum not only for empirical research studies but also for developments in theory, analytical solutions to research questions, and multidisciplinary

Roberto Di Pietra

roberto.dipietra@unisi.it

Günther Gebhardt

blonski@wiwi.uni-frankfurt.de

Stuart McLeay

S.J.Mcleay@sussex.ac.uk

1 University of Siena, Siena, Italy

2 Goethe-Universität, Frankfurt, Germany

3 University of Sussex, Brighton, UK 
approaches to policy-oriented analysis. The Workshop papers addressed contentious issues underlying compliance with regulations, consideration of standard setting processes, the processes of audit oversight, and regulatory legitimacy. Other topics included the connections between regulation and accounting quality, accruals and fair values, the interconnections with compensation regimes and value relevance, and the more specific challenges facing regulated organizations in the public sector, banks and SMEs.

Of the papers submitted for consideration for this Special Issue, we obtained full referee reports on those short-listed and seven were selected for publication. Together, they reflect the great breadth of debate at the Siena Workshop. Yanmin Gao and Alfred Wagenhofer investigate board decisions to retain or replace an incumbent manager, and explain why firms with strong corporate governance in this context are likely to exhibit more conservative accounting. Camélia Radu and Samaneh Maram evaluate a recent mandate for carbon emissions disclosures, and explain why there has been a negative association between reported greenhouse gas emissions and firm value. Esther Pittroff discusses the legitimacy of accounting regulation from the view of path-dependence theory, considering how the real convergence of accounting standards might or might not be achieved. Alberto Quagli, Corrado Lagazio and Paola Ramassa construct an innovative indicator for empirical researchers that measures the breadth of control over financial reporting that is exercised through the combination of corporate governance, audit and enforcement. In the context of recent amendments to audit regulations, Sandro Brunelli, Chiara Carlino, Rosella Castellano and Alessandro Giosi investigate investor reaction to audit reports that contain a going concern modification. Shruti Kashyap and Einar Iveroth present an in-depth case study of the impact on risk management by a large listed bank when international guidelines on internal governance are implemented through domestic financial regulation. Finally, Pierre Donatella and Torbjörn Tagesson demonstrate how opportunistic accounting choice decreases with CFO tenure and experience in the context of accounting by municipalities, following a sector-specific statement issued by their standard-setting body.

Order to collect the seven accepted papers belonging to this Special Issue:

1. Gao and Wagenhofer (MAGO-D-19-00205 R3);

2. Camélia Radu and Samaneh Maram (MAGO-D-19-00302 R2);

3. Esther Pittroff (MAGO-D-19-00288 R2);

4. Alberto Quagli, Corrado Lagazio and Paola Ramassa (MAGO-D-19-00307 R2);

5. Sandro Brunelli, Chiara Carlino, Rosella Castellano and Alessandro Giosi (MAGO-D-19-00303 R3);

6. Shruti Kashyap and Einar Iveroth (MAGO-D-19-00298 R2);

7. Pierre Donatella and Torbjörn Tagesson (MAGO-D-19-00259 R3). 
Publisher's Note Springer Nature remains neutral with regard to jurisdictional claims in published maps and institutional affiliations.

Roberto Di Pietra is a full Professor in Accounting and Business Administration at the Department of Business and Law Studies, University of Siena. He completed his postgraduate studies with a Banking specialization in 1993, and received a Ph.D. in Accounting and Business Administration from the University of Pisa in 1997. His main research interests are in International Accounting and Auditing (Accounting regulation, IFRS and financial statements, IFRS and corporate governance, IAS and organizational learning), and in Accounting History. Roberto Di Pietra is Past and Contributing Editor of the Journal of Management and Governance, Past President of the Italian Society of Accounting History, member of the EFRAG Academic Panel and Director of the Department of Business and Law Studies (University of Siena). He is also editorial board member of Accounting in Europe, Financial Reporting and Revista Espanola de Contabilidad y Financiaccion de Empresa.

Günther Gebhardt holds a diploma degree in economics and business administration from Ruhr-Universität Bochum where he also earned his doctoral degree and his post doctorate habilitation degree. Before joining Goethe-Universität, he was Professor of Finance at Universität Bamberg and Professor of Business Administration at Universität Münster. He has held visiting positions at the Wharton School, University of Pennsylvania, at New York University and at the University of Sydney. His research interests include international corporate finance and international accounting, including accounting for mergers \& acquisitions, financial instruments and financial institutions. He has been involved in standard setting as a member of the Joint Working Group of Standard Setters on Financial Instruments and as the Chair of the EAA Financial Reporting Standards Committee. Günther Gebhardt has published several books and many articles in leading German and international journals, including Abacus, Accounting and Business Research, European Accounting Review, Journal of Business Finance \& Accounting.

Stuart McLeay is Emeritus Professor of Accounting and Finance in the University of Sussex, and an Honorary Professor in the University of Sydney. As a qualified chartered accountant, he gained practical experience as an auditor living and working in the UK, France, Germany and Italy, and then as a financial analyst with the European Investment Bank. After obtaining a PhD from the University of Lancaster, he edited the ICAEW's European Financial Reporting series, and became a faculty member of the European Commission's initial research training initiative on The Regulation of Financial Reporting in Europe, and editor of the resulting book Accounting Regulation in Europe. He then coordinated the successful HARMONIA research training programme, which was also funded by the European Commission, and continued as a member of the subsequent INTACCT research training network faculty. Stuart McLeay has recently published Economic Impact and Statistical Significance, an ICAEW Research Briefing on the interpretation of accounting research results for evidence-based policy making. 